\title{
Environmental Characteristics: Moderator of Strategic Planning Process Formality and Performance
}

\author{
Peter Agyekum Boateng* \\ Valley View University, P. O. Box 183, Techiman, Ghana \\ *Corresponding Author: Peter Agyekum Boateng, Valley View University, P. O. Box 183, Techiman, \\ Ghana
}

\begin{abstract}
The study considered the dynamics of environmental factors and the extent to which they moderate the influence strategic planning process formality has on performance. Approach to the study was descriptive, ex-post facto survey. A multiple constituency approach was used for performance measurement. Environmental characteristics incorporated a five-item environmental turbulence scale. Relationships between the variables (SPPF, DYNA, PERF) were analyzed with bivariate correlation, binary logistic regression test, and linear regression. Higher degrees of strategic planning process formality enhanced performance in environments where demand and customer tastes could fairly and easily be forecasted. Increased adherence to established standards (higher degrees of strategic planning process formality) is recommended for achieving desired outcomes.
\end{abstract}

Keywords: Strategic Planning Process Formality, Environmental Characteristics, Performance

\section{INTRODUCTION}

Strategic planning processes do not seem to have significant influence on the performance of institutions due to some perceived level of negligence in acknowledging the contribution of environmental factors. The process appears to have become routine exercise without due consideration to elements within its environments (O'Regan \& Ghobadian, 2007, in Boateng et al., 2015). Many plans are shelved and do not influence output as a result of this (Bracker\& Pearson, 1986). Business environments seem to have been changing - and so should institutional approaches. The study has therefore examined environmental characteristics of institutions, and the volume of their moderated influence on the relationship between their strategic planning processes and performance. It provides institutions with broader understanding of their environments, and how to smoothly adapt internal resources for enhanced performance. It informs decision makers, the strategies to pursue for enhanced performance, based on characteristics within their environments. The hypotheses tested at 0.05 level of significance was that environmental characteristics have no significant moderating influence on the strategic planning process formality-performance relationship. This hypothesis is influenced by the dynamic capabilities theory, and contingency theory. The ability to identify and analyze environmental factors could lead to better strategic choices for improved performance. The environments are considered key contingency variables for relationships between strategy and performance.

\section{REVIEW OF LITERATURE}

Strategic Planning Process: The genesis of formal strategic planning in 1950's was led by Druker (Odongo \& Datche, 2015). Many studies have defined strategic planning in diverse ways. Ansoff (2007, cited in Moussetis, 2014) viewed strategy planning as the common thread in an organization's business growth and product scope. Strategic planning also deals with making long-term decisions that enable organizations respond to changing environments. According to Johan, Thompson and Strickland (2010), strategic planning is a process, and it involves assessment of threats and opportunities, weaknesses and strengths in changing environments. Strategies are laid down to cope with problems, with institutional goals in view. Johan, Thompson and Strickland (2010) further define strategic planning as management tool that uninterruptedly and systematically evaluates a business, identifies its long-term goals and quantifiable objectives, develops a plan to implement, monitor performance, allocate resources, redefine the plan where need be, to ensure the organizational 
members work towards the defined goals in changing environment. Current studies demonstrate that strategic planning helps in decision making as it focuses attention on relevant environmental issues and challenges an organization faces and further assist decision makers chart a path into the future (Bryson, 2018). The evidence is fairly clear that organizations that are managed well and are relatively stable perform better, are properly responsive to external needs, are innovative in effective ways, have enormous influence, are more accountable, and are more resilient (Borins, 2014; Meier \& O'Toole, 2009).

A strategic planning process is germane to every institution's survival because it is the process by which the institution adapts to its ever-changing environment, and the process is applicable to all management levels and all types of institutions (Karim, 2018). This gives the indication that the process is relevant to the assessment and forecasting of the external environment as it keeps changing to ensure organizational survival. Karim (2018) identified this systematic planning exercise as involving series of phases to determine the present status of the business, including its mission, vision for the future, needs, objectives, actions and strategies' priorities, action plans and monitoring and evaluation programs. The environments of an organization influence its capacity and the ability of individuals to build or discover opportunities (Muhammad, 2014; Karim, 2018).

Strategic Planning and the External Environment: Previous research revealed significant relationship between strategic planning and organizational performance. In addition to this, researchers demonstrate that for enhanced performance, there is the need to create significant information and understanding of the environments within which organizations operate. For this reason, strategic planning deals with making long-term decisions that make organizations responsive to changing environments. Environments, according to Kowo (2018), does not specifically mean physical surroundings but instead used to explain all the influences that bear upon the individual organization. Environmental characteristic is used to mean anything within the surrounding of an organization. It encompasses external variables which cannot be easily controlled by management (Bayode\& Adebisi, 2012). However, the nature of the environment can be characterized with both internal and external factors. Oginni and Adesanya (2013) posited that the internal environment of a business is controlled by circumstances such as policy, personnel, capital and others while the external consist of factors outside the control of institutions - political, economic, social, technological and government legislation. Johnson et al.(2008, cited in Adu, 2016) identified macro external factors, industry factors and competitors and market as essential elements of external environment of an organization.

Environmental characteristics are environmental forces beyond the control of management but influences the activities of firms (Shrader, Mulford, \& Blackburn, 1989). 'Dynamism' or 'volatile' environment are all related to the frequency and speed of environmental change (Grant, 2003; Glaister, Dincer, Tatoglu, Demirbag, \& Zaim, 2008; Ansof, 1970). Environmental dynamism refers to "the degree of instability or turbulence of such key operating concerns as market and industry conditions as well as more general technological, economic, social, and political forces" (Mohd, Idris, \& Momani, 2013:41; see also Dess \& Beard, 1984). It refers to the rate of change, absence of pattern and unpredictability of the environment. Environments have been viewed as key contingency variables for relationships between strategy and performance (Schwenk\&Shrader, 1993). Understanding the nature of the environments and how they manipulate organizations, therefore, requires some attention. Adeoye (2013) attests that to cope with the unstable and rapidly changing environments, there is the demand to create and execute proper strategies that would safeguard their functions and produce desired targets (see also Arasa and K'Obonyo, 2012).Prescott (1986) noted that the environment establishes the context that allows evaluation of various relationships between strategy and performance. Greenley and Foxall (1997, in Glaister et al., 2008) comment that even though strategic planning, to some extent, affects performance, the relationship is influenced by the external environment. "Dynamic business environments may be characterized by changes in various market elements, such as customer preferences, technology and competitor structure" (Mohd et al., 2013:41). It is defined with reference to the unpredictability of the environment. It has been mentioned that the level of uncertainty is higher during the emergent levels of environmental dynamism, which in turn reduces the predictability and effects of change (Iansity 1995; in Mohd et al., 2013).

Strategic Planning and Performance: Germano and Stretch-Stephenson (2012) argued that strategic plans are developed and executed by businesses to chart a course toward an idealized future 
destination. According to Michael, Shirley and Stretch-Stephenson (2012), this means aspiring to become an institution leader or niche holder by increasing market share, developing customer loyalty, penetrating new markets or some other defined goal that is ultimately premised on growth in revenue attainment. Currently, strategies demand the development of plans that embrace customer engagement to improve revenue. For these reasons, several researches have demonstrated the effective role of strategic planning on institutional performance (Mcllquham-Schmidt, 2010; Wang, Walker \& Redmond, 2007). The correlation between strategic plan and performance of institution has been largely studied (Suklev \& Debarliev, 2012;Aldehayyat\&Twaissi, 2011; Ida, Azahari, Munauwar \& Rushami, 2015). Aldehayyat and Khattab (2013) suggested that utilizing mechanisms of strategic planning would assist in achieving better performance.

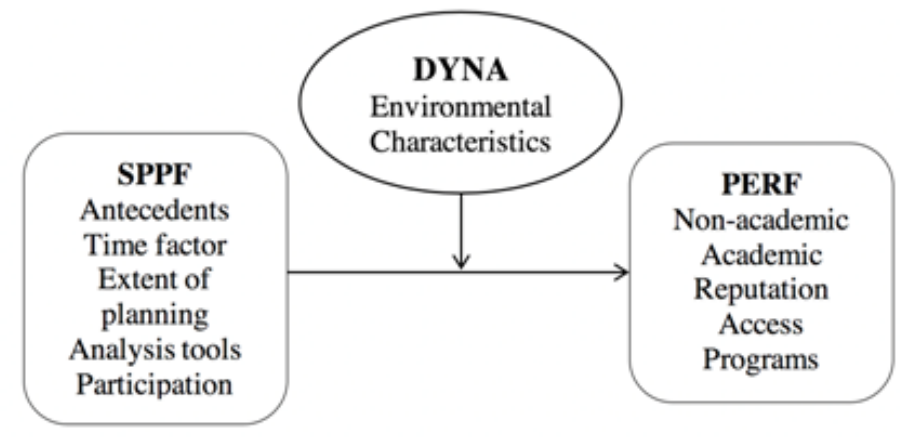

Fig1. Conceptual model (2014).

Key: SPPF - Strategic Planning Process Formality; DYNA - Environmental Characteristic; PERF - Performance.

The dynamic capabilities framework answers the question of how some organizations are able to securely achieve competitive advantage in dynamic markets (Ferdinand, J., Graca, M., Antonacopoulou, E., \&Easterby-Smith, 2004). The approach "analyzes the sources and methods of wealth creation... by private enterprise firms operating in environments of rapid technological change" (Teece, D. J., Pisano, G., \&Shuen, 1997:509). It is an extension to the resource-based theory which is static and does not account for market dynamism (Priem\& Butler, 2001; Poulis, Poulis, \& Christodoulou, 2013). The dynamic capabilities theory aims at considering how to develop and maintain a firm's resources over time (Teece et al., 1997) due to changing environments, then make better strategic choices for improved performance.

Contrary to the classical approach (scientific management) which assumed the 'one best way' to manage organizations (Kinicki \& Williams, 2011), contingency theory emphasizes that a manager's approach to strategy should depend on individual environmental situations. There is the likelihood that environmental factors could determine the extent of the relationships between strategy and performance."Different external conditions might require different organizational characteristics, and that the effectiveness of the organization is contingent upon the amount of congruence or goodness of fit between structural and environmental variables" (Lawrence \& Lorsch, 1967; in Shenhar, 2001:395). It is improbable to have universally applicable management principles due to environmental variances. Organizations differ from each other with different situations [contingencies] that require different ways of managing (see also Robbins \& Coulter, 2012; Bracker\& Pearson, 1986; Bahaee, 1992). Organizations are expected to approach management with their varied firm contexts in view - recognize and respond to situational variables as they arise (Robbins \& Coulter, 2012).

The literature has re-emphasized the magnitude of benefits of strategic plans, influenced by certain industrial characteristics (Shraeder, 2002). Miller and Cardinal (1994)found that the relationship between strategic planning and performance was more noticeable in organizations that operated in turbulent environments. Risseeuw and Masurel (1994) also found that uncertainty caused by environmental complexity has positive influence on the planning sophistication, although this is not confirmed as statistically significant and that the planning intensity is highest in an environment that is perceived as moderately dynamic. Planning intensity in this case refers to the frequency of strategic planning.

An initial study by Arasa and K'Obonyo (2012) examined the relationship between strategic planning and firm performance focusing its attention on strategic planning process in Kenya. The study 
presented a significantly positive relationship between strategic planning and firm performance. All the strategic planning process which include defining institution's objective, scanning of business environment, identification of firms' strategic issues strategy choice and setting up implementation, evaluation and control system were found to be significantly correlated to firm performance. Aldehayyat and Twaissi (2011) also confirmed a statistically positive relationship between strategic planning and firm's performance. Ida, Azahari, Munauwar, and Rushmi (2015) declared that strategic planning makes vital contribution to the performance of an institution.

Nooraie (2012) and Priem, Rasheed, and Kotulic (1995) also suggested that the extent of rationality in strategic decision-making process is positively related to performance in dynamic environments, while less rationality is associated with high performance in stable environments. Debarliev and Trpkova (2011) noted that the application of structural strategic planning made entrepreneurs better prepared for anticipating and coping with future changes. Additionally, Burns and Stalker (1961, in Chae\& Hill, 2000:542) reported that "organizational structures with lower centralization and formalization characteristics were better suited to more dynamic environments". Chae and Hill (2000) noted that the impact of turbulent environments on planning formality has been researched but with mixed conclusions.

Boulton et al. (1982, in Chae\& Hill, 2000:542) concluded that "uncertainty did not consistently impact strategic planning". Bresser and Bishop (1983, in Chae\& Hill, 2000:542) also argued that "comprehensive planning in uncertain and complex environments caused more problems than it solved". The writers believed that the needed creativity for spontaneous response in a fast-changing environment may be hindered by formal planning procedures. Since it is the aim of formal strategic planning to guide the organization through its uncertain environments, it then holds that the ability to anticipate and make accurate strategic future choices may possibly lead to enhanced performance. In this sense, strategic planning may be more useful in a turbulent environment than in a stable one (Armstrong, 1982; Miller \& Cardinal, 1994; in Glaisteret al., 2008). The correlation between planning and performance may be stronger in a turbulent environment and weaker in a placid environment, hence environmental turbulence leads to greater incidence, formalization and effectiveness of strategic planning (Glaisteret al., 2008).

Falshawet al. (2006) state that the strategic planning frequency increases as environmental turbulence increases, which is confirmed by the research of many authors from this area (Boyd \&Reuning-Elliott, 1998; Eisenhardt, 1989; Shraeder, 2002; Armstrong, 1982). The empirical evidence is mixed. While some studies find strategic planning more useful in a dynamic (turbulent) environment, according to Glaister et al (2008; see also Eisenhardt, 1989; Miller \& Cardinal, 1994), others argue that increasing turbulence could lead to reduced reliance on formal planning systems and greater reliance on experience or other informal systems; the impact is likely to be positive in a stable environment where predictions are easier (Fredrickson \& Mitchell, 1984). Wilson (1994, cited in Grant, 2003) found that external instability led to greater informality (e.g. less documentation and more flexible schedules). Also, Kukali (1991, in Grant, 2003) observed that increased rates of external change increased the flexibility of planning practices. This does not mean less detailed plans. Organizations attempt to handle environmental uncertainty with greater planning efforts (Grant, 2003).

The use of formal planning is more common with firms in complex environments (Lindsay \& Rue, 1980; in Chae and Hill 2000). Furthermore, Chae and Hill (2000:542) report a study conducted by Kukalis $(1989,1991)$ which concluded that planning is extensive and short-termed, and frequently reviewed where environmental complexity is high. Environmental complexity is also positively associated with strategic planning formality (Wiersema \&Bantel, 1992). Shenhar (2001) observes that mechanistic firms should perform better in simple, stable, and more certain environments while an organic firm is best for uncertain environments. Along the same line, Miller (1987) also noted that formalization positively impacted formal strategic choices. "A high level of uncertainty in the environment therefore requires less formalized and more flexible structures, and more complex but flexible departments and roles (Lawrence \& Lorsch, 1967, cited in Glaisteret al., 2008). (Unfavorable: The trend seems to be uniform, but Mintberg (1979, in Glaisteret al., 2008) notes that support for these arguments has not been consistent in the literature.

Organic or less formalized organizational structures operating in highly uncertain and more dynamic environments appear to positively affect the link between strategic choices and organizational performance (Miller \& Cardinal, 1994; Glaisteret al., 2008; Nooraie, 2012). According to Glaisteret 
al. (2008), Boyd \&Reuning-Elliott (1998) contend that the relationship between strategic planning and performance is stronger in a more dynamic environment but weaker in a stable environment. Miller and Cardinal (1994) also found that the relationship between strategic planning and performance was more noticeable in organizations that operated in turbulent environments. Strategic planning may be more useful in a turbulent environment than in a stable one (Armstrong, 1982; Miller $\&$ Cardinal, 1994). The extent of rationality in strategic decision-making process is positively related to performance in dynamic environments, while less rationality is associated with high performance in stable environments (Glaisteret al., 2008; Nooraie, 2012).

\section{Methodology}

The descriptive, ex-post facto survey was the approach used in this study. Sampling units consisted of strategic planning committees of accredited degree awarding private institutions of higher learning. Eighty-four 84 responses were retrieved from 26 institutions. Questionnaire was adapted from Glaisteret al., 2008.Respondents were asked to indicate the extent of their agreements/disagreements with each questionnaire item.

The areas of concern for strategic planning process formality (SPPF) included antecedent and process dimensions, time factor, extent of planning, strategic analysis techniques, and participation in planning. Institutional performance was measured with a multiple constituency model by Abdullah (2006). The areas measured were reputation, academic, non-academic, access, and program issues. The moderator variable of interest was environmental characteristics (the environment is either dynamic or stable). These were operationalized to specify the functional relationships and analytical models that clarified the links between them.

Table1. Environmental Characteristics Scale

\begin{tabular}{|l|l|l|}
\hline \multicolumn{1}{|c|}{ Dynamic (0) } & & \multicolumn{1}{|c|}{ Stable (6) } \\
\hline $\begin{array}{l}\text { Our firm must change its marketing practices } \\
\text { extremely frequently (e.g. semi-annually). }\end{array}$ & DYNA1 & $\begin{array}{l}\text { Our firm has to change its marketing practices } \\
\text { to keep up with the market and competitors. }\end{array}$ \\
\hline $\begin{array}{l}\text { Threat of obsolescence is very high, as in } \\
\text { some fashion goods. }\end{array}$ & DYNA2 & $\begin{array}{l}\text { The rate at which products or services are } \\
\text { getting obsolete in the industry is very slow } \\
\text { (e.g., academic programs). }\end{array}$ \\
\hline Actions of competitors are unpredictable. & DYNA3 & $\begin{array}{l}\text { Actions of competitors are quite easy to } \\
\text { predict. }\end{array}$ \\
\hline Demand and tastes are almost unpredictable. & DYNA4 & $\begin{array}{l}\text { Demand and customer tastes are fairly easy to } \\
\text { forecast. }\end{array}$ \\
\hline $\begin{array}{l}\text { The modes of service change often and in a } \\
\text { major way. }\end{array}$ & DYNA5 & $\begin{array}{l}\text { The sechnology is not subject to very } \\
\text { much change and is well established. }\end{array}$ \\
\hline
\end{tabular}

Source: Glaisteret al. (2008)

Operationalization of environmental characteristics incorporated a five-item 'Environmental Turbulence Scale' of Glaister et al. (2008): DYNA1 - DYNA5 (see Table 1). This scale was patterned after Miller and Droge's (1986) environmental uncertainty measure, which was also based on the measures of Khandwalla (1974, 1977; in Glaisteret al., 2008). On a scale of 1 to 6, respondents were asked to indicate the intensity or rapidity of each item within their environments.

Logistic function was used to model the binary dependent variable. Environmental characteristics questionnaire items that had significant interaction with SPPF toward influencing PERF were determined with binary logistic regression. This contextual variable (DYNA4) was standardized and moderated with the criterion variable. The volume of the moderated variable's (DYNA4) influence on the strategic planning process-performance (SPP-PERF) relationship was then determined with linear regression. The standardized scores of DYNA4 were multiplied by the composite value of SPPF. This sought to properly quantify DYNA4's influence.Results were regressed on PERF to determine the extent of DYNA4's moderating influence.

\section{Data Presentation AND Discussion}

The study focused on moderating effects of environmental dynamics on the SPPF-PERF relationship. Efforts to adhere to rules towards long term planning were found to have been given attention over emergent, flexible planning. The planning processes of most institutions were more formal than flexible, as seen in Table 2 (Boateng et al., 2015). 
Table2. Strategic Planning Process Formality

\begin{tabular}{|l|c|c|}
\hline \multicolumn{1}{|c|}{ Categories } & Frequency & Percent \\
\hline A: Flexibility & 22 & 26.2 \\
\hline B: Formality & 62 & 73.8 \\
\hline Total & 84 & 100.0 \\
\hline
\end{tabular}

Source: Boateng et al. 2015

Performance measurement focused on five areas: non-academic, academic, reputation, access, and programme issues (Abdulai, 2006, in Boateng et al., 2015). The scale ranged from 'very poor' to 'very good'. Areas that needed attention were Non-academic aspects and Access. Performance was 'Poor' among $36.9 \%$ of institutions, and 'Good' among $63.1 \%$ of institutions. It was normally skewed at $-0.14(-0.5 \geq 0 \leq+0.5)$. Overall performance (mode $=3.8$ ) was therefore rated 'fairly good' (see also Boateng et al., 2015).

Table3. Linear Regression of SPPF and PERF (Coefficients ${ }^{a}$ )

\begin{tabular}{|c|c|c|c|c|c|c|c|}
\hline \multirow[t]{2}{*}{ Model } & \multicolumn{2}{|c|}{$\begin{array}{l}\text { Unstandardized } \\
\text { Coefficients }\end{array}$} & \multirow{2}{*}{$\begin{array}{c}\begin{array}{c}\text { Standardized } \\
\text { Coefficients }\end{array} \\
\text { Beta } \\
\end{array}$} & \multirow[t]{2}{*}{$\mathbf{t}$} & \multirow[t]{2}{*}{ Sig. } & \multicolumn{2}{|c|}{$\begin{array}{l}\text { 95.0\% Confidence Interval for } \\
\text { B }\end{array}$} \\
\hline & $\beta$ & Std. Error & & & & Lower Bound & Upper Bound \\
\hline 1 (Constant) & 3.818 & 3.060 & & 1.248 & .216 & -2.269 & 9.904 \\
\hline SPPF & .091 & .020 & .444 & 4.485 & .000 & .051 & .131 \\
\hline
\end{tabular}

a. Dependent Variable: PERF

Source: Field survey (2014; see also Boateng et al. 2015)

Performance was 3.818 in the absence of strategic planning process formality. Table 3 reveals that performance improves by $9.1 \%$ with a unit increase in the degree of strategic planning process formality. On the other hand, a unit decrease in the degree of formality led to a $9.1 \%$ decrease in performance (see also Boateng et al., 2015).Environmental Characteristics refer to the frequency at which components within institution's environments change; more frequent (dynamic) or less frequent (stable). Lower ratings on a six-point Likert scale (Table 1) meant dynamic (frequently changing) environments, while higher ratings indicated stable environments.

Table4. Binary Logistic Regression - Variables in the Equation

\begin{tabular}{|c|c|c|c|c|c|c|c|}
\hline & & $\boldsymbol{\beta}$ & S.E. & Wald & Df & Sig. & $\operatorname{Exp}(\beta)$ \\
\hline \multirow[t]{2}{*}{ Step $2^{b}$} & DYNA4 & .482 & .191 & 6.353 & 1 & .012 & 1.619 \\
\hline & Constant & -4.313 & 1.516 & 8.093 & 1 & .004 & .013 \\
\hline \multicolumn{8}{|l|}{ Step $3^{c}$} \\
\hline & DYNA4 & .546 & .202 & 7.291 & 1 & .007 & 1.726 \\
\hline & Constant & -5.703 & 1.771 & 10.368 & 1 & .001 & .003 \\
\hline
\end{tabular}

Source: Field survey (2014)

The relationships between strategic planning process formality (SPPF) and the moderator (DYNA4) was represented by the following model: SPPF $=-5.703+0.546 \mathrm{DYNA} 4$. Of the five (5) variable items describing the environments, DYNA4 was identified as the best fit moderator variable that interacted with SPPF. DYNA4 sought to determine whether demand and customer tastes were almost unpredictable (dynamic), or were fairly easy to forecast (stable). The environments were 59.5\% stable, and $40.5 \%$ dynamic. The probability for DYNA4 $(\mathrm{p}=0.007)$ to influence formal strategic planning was extremely high (Table 4) - DYNA4 significantly favors formal planning over flexible planning.

Table5. Moderator Skewness

\begin{tabular}{|c|c|c|c|c|c|c|c|c|}
\hline & $\mathbf{N}$ & Minimum & Maximum & Sum & Mean & Std. Deviation & \multicolumn{2}{|c|}{ Skewness } \\
\hline & Statistic & Statistic & Statistic & Statistic & Statistic & Statistic & Statistic & $\begin{array}{c}\text { Std. } \\
\text { Error }\end{array}$ \\
\hline DYNA4 & 84 & 1 & 6 & 297 & 3.54 & 1.602 & -.192 & .263 \\
\hline
\end{tabular}

Source: Field survey (2014)

DYNA4 was -0.73 skewed - most environments with higher degrees of SPPF were stable. The Pearson Correlation Coefficients for DYNA4 and SPPF (Table 8) reported the existence of some 
significant (but not so strong) degree of association between DYNA4 $(r=0.285 ; p=0.008)$ and SPPF at the 0.01 level of significance.

The study eventually focused on the value of the SPPF-PERF relationship in the absence of external influences, amount of influence DYNA4 adds to the relationship, and, the estimated error of the model. To properly quantify the influence of DYNA4 on the SPPF-PERF link, its standardized scores were multiplied by the composite value of SPPF. The results were then regressed on PERF to determine the moderating influence of DYNA4.

Table6. Moderated DYNA4 on SPPF-PERF Relationship

\begin{tabular}{|c|c|c|c|c|c|c|c|}
\hline \multirow[t]{2}{*}{ Model } & \multicolumn{2}{|c|}{$\begin{array}{l}\text { Unstandardized } \\
\text { Coefficients }\end{array}$} & \multirow{2}{*}{$\begin{array}{c}\begin{array}{c}\text { Standardized } \\
\text { Coefficients }\end{array} \\
\text { Beta } \\
\end{array}$} & \multirow[t]{2}{*}{$\mathbf{t}$} & \multirow[t]{2}{*}{ Sig. } & \multicolumn{2}{|c|}{$\begin{array}{l}\text { 95.0\% Confidence } \\
\text { Interval for B }\end{array}$} \\
\hline & B & $\begin{array}{c}\text { Std. } \\
\text { Error }\end{array}$ & & & & $\begin{array}{l}\text { Lower } \\
\text { Bound }\end{array}$ & $\begin{array}{l}\text { Upper } \\
\text { Bound }\end{array}$ \\
\hline 1 (Constant) & 13.689 & 1.195 & & 11.454 & .000 & 11.311 & 16.066 \\
\hline $\begin{array}{l}\text { Moderated } \\
\text { DYNA4 }\end{array}$ & .007 & .002 & .352 & 3.410 & .001 & .003 & .011 \\
\hline
\end{tabular}

a. Dependent Variable: Institutional Performance

Source: field survey (2014)

PERF in the absence of the moderated DYNA4 is 13.689 (Table 6). The SPPF-PERF relationship is increased by 0.7 percent with a unit increase in the moderated variable (DYNA4), holding all other independent variables constant. The $t$ statistic value of 3.410 was also significant $(p=0.001)$.

Table7. Model Summary - Moderated DYNA4 and SPPF-PERF Link

\begin{tabular}{|l|c|r|r|r|r|r|r|r|r|}
\hline Model & $\mathbf{R}$ & \multirow{2}{*}{$\begin{array}{c}\mathbf{R} \\
\text { Square }\end{array}$} & $\begin{array}{c}\text { Adjusted R } \\
\text { Square }\end{array}$ & $\begin{array}{l}\text { Std. Error of } \\
\text { the Estimate }\end{array}$ & \multicolumn{4}{|c|}{ Change Statistics } \\
\cline { 5 - 9 } & & & & & $\begin{array}{l}\text { R Square } \\
\text { Change }\end{array}$ & $\begin{array}{c}\text { F } \\
\text { Change }\end{array}$ & df1 & df2 & $\begin{array}{c}\text { Sig. F } \\
\text { Change }\end{array}$ \\
\hline 1 & $.352^{\mathrm{a}}$ & .124 & .114 & 4.773 & .124 & 11.628 & 1 & 82 & .001 \\
\hline
\end{tabular}

a. Predictors: (Constant), Standardized DYNA4

b. Dependent Variable: Institutional Performance

Source: field survey (2014)

Indicates that DYNA4 accounted for 12.4 percent of the variation in the SPPF-PERF relationship, with a corresponding standardized error of 4.956 (Table 7). About 87.6 percent of variation in the SPPF-PERF relationship was explained by other factors. Table 8 indicates that there existed some significant degree of association between DYNA $(r=0.285 ; \mathrm{p}=0.008)$ and SPP at the 0.01 level of significance. The relationship did not seem stronger.

Table8. Pearson Correlation Coefficients - DYNA and SPP

\begin{tabular}{|l|l|l|l|}
\hline \multicolumn{2}{|l|}{} & \multicolumn{1}{c|}{ DYNA } & \multicolumn{1}{c|}{ SPPF } \\
\hline \multirow{2}{*}{ DYNA } & Pearson Correlation & 1 & $.285^{* * *}$ \\
\cline { 2 - 4 } & Sig. (2-tailed) & & .008 \\
\hline \multirow{2}{*}{ SPP } & Pearson Correlation & $.285^{* *}$ & 1 \\
\cline { 2 - 4 } & Sig. (2-tailed) & .008 & \\
\hline
\end{tabular}

$* *$ Correlation is significant at the 0.01 level (2-tailed).

Source: Field survey (2014).

Key: DYNA - Environmental dynamism; SPPF - Strategic Planning Process Formality

DYNA4 sought to determine whether demand and customer tastes were almost unpredictable (dynamic), or were fairly easy to forecast (stable). The model favoured the later. Table 5 reports that DYNA4 is -0.73 skewed. Again, there was $59.5 \%$ indication that institutions operated within stable environments, and $40.5 \%$ within dynamic environments. Higher degrees of planning formality improve performance in less dynamic environments (Capon et al. (1994; cited in Boateng et al., 2015). This therefore highlights the importance of a systematic strategy formalization process (Dutton \& Duncan, 1987). The environments of most institutions with higher degrees of SPPF were stable customer tastes were easily predictable. Table 8 shows that there was some degree of association 
between DYNA4 $(r=0.285 ; \mathrm{p}=0.008)$ and SPPF at the 0.01 level of significance. This translated into higher degrees of SPPF as the environments of the institutions progressed from dynamism to stability. The SPPF-PERF relationship was improved by 0.7 percent with a unit increase in each presented opportunity to fairly and easily predict environmental changes, holding all other variables constant. Hence, a unit increase in such ability to forecast (from dynamic toward stability) made the strategic planning process 0.7 percent more effective. In such environments, plans do not change frequently and makes room for long term decisions. Institutions whose performance was good due to their acquired predictability skills, and pursued higher degrees of formal strategic planning processes were $73.2 \%$ higher than any group (institutions with more relaxed formality). Those whoadopted planning process flexibility had 50\% poor performance. In summary, higher degrees of SPPF enhances performance in a stable, predictable environment.

Hypothetically, a unit increase in DYNA4 significantly influenced the SPPF-PERF link by 0.7 percent with a significant $t$ statistic value of $3.410(\mathrm{p}=0.001)$, as seen in Table 6 . With a unit increase in the ability to fairly and easily forecast demand and customer tastes, the strategic planning processes were more effective towards enhancing performance (by 0.7\%). Environmental characteristics were here seen to moderate the SPPF-PERF relationship. The study therefore failed to accept the null hypothesis that, environmental characteristics have no significant moderating influence on the relationship between formal strategic planning and performance.

To a larger extent, institutional decision makers have no control over the environments within which they operate. The environment establishes the context for evaluating the relationship between strategic planning process and performance (Prescott, 1986). Structures therefore should be modified as environmental changes are noticed, for enhanced performance. Robbins and Coulter (2012) also adds that an environment's degree of change and/or its complexity influences an organization's strategyperformance relationship (see also Grant, 2003; Glaister et al, 2008). The link is enhanced where, in a stable environment, institutions adopt a mechanistic structure with formal strategic planning processes.

Strategic planning process formality, per other studies, increases with increased environmental turbulence; the relationship gets weaker in a stable environment (Debarliev\&Trpkova, 2011; Falshaw et al., 2006). In a similar study among Turkish companies, Glaister et al. (2008) found that environmental turbulence moderates positive relationship between SPPF and firm performance. Falshaw et al. (2006) also found that dynamic environments lead to more formalized planning systems for improved performance. These findings confirm earlier studies (Armstrong, 1982; Miller and Friesen, 1983; Eisenhardt, 1989; Boyd \&Reuning-Elliott, 1998; Miller and Cardinal, 1994).

Others argue that increased environmental dynamism rather leads to greater dependence on experience and other informal skills decreasing the need for formal planning systems. The current study favours the latter. The need for formal planning systems increases with decreased environmental turbulence, for improved performance (Mintzberg, 1993; Fredrickson \& Mitchell, 1984; Johnson, Scholes, \& Whittington, 2008). Asika (2011), also explains that environmental failures (environmental, economic, legal, and managerial) happen at a level where business fails to respond to impacts due to environmental changes. The Ghanaian business environment seems to be more certain and stable. Per available responses, predictability is fairly easy - signaling a stable environment. Such environment promotes the ability to place strong emphasis on getting personnel to follow laid down procedures - which is not possible in dynamic environments where planning may be frequent. The certainty of the Ghanaian environment (ability to predict demand) allows for long term planning.

\section{CONCLUSION AND RECOMMENDATIONS}

The purpose of planning is to enhance the ability to perform efficiently and effectively. In the study, performance improved as institutions resorted to more aggressive strategic planning processes within stabilized and predictable contexts. The performance of institutions whose strategic planning processes showed some higher levels of formality was better. This therefore is in tandem with proposals that strategic planning processes should be active and working systems, and notmere repetition of courses of actions thatare predicted, charted, and shelved. Per this study, SPPF involves the ability to conceptualize an institution in its entirety to determine the best possible alternatives for goal attainment. 
It is established that to some extent, environmental components are likely to moderate strategic planning processes' influence on performance. Decisions to improve institutional performance, in light of established strategic planning processes should not ignore environmental factors, such as the ease with which demand is predicted. This therefore requires structural modification as environmental changes are noticed, for enhanced performance. In an environment where demand and customer tastes are easily and fairly forecasted, it is recommended that institutions focus on higher degrees of strategic planning process formality(SPPF), where, higher degrees of formality imply strict compliance to strategic planning processes. higher degrees of strategic planning process formality should be pursued as institutions grow in stable environments.

\section{LIMITATIONS AND SUgGeSTIONS FOR FUTURE STUDIES}

This study was limited in its evaluation of performance. Future efforts may consider other performance measures outside academics, reputation, non-academics, access, and programmes. Moderating influence of specific environments (economic, political, socio-cultural, legal, etc) could also be the focus of future research activities.

\section{REFERENCES}

[1] Abdullah, F. (2006). The development of HEdPERF: a new measuring instrument of service quality for the higher education sector. International Journal of Consumer Studies, 30(6), 569-581.

[2] Abdullah, F. (2006a). Measuring service quality in higher education: HEdPERF versus SERVPERF. Marketing Intelligence \& Planning, 24(1), 31-47.

[3] Abdullah, F. (2006b). Measuring service quality in higher education: three instruments compared. International Journal of Research \& Method in Education, 29(1), 71-89.

[4] Abolaji, O. \& Oni, I. (2015). The effect of internal environment on the performance of small and medium scale enterprise in Kano metropolis. International Journal of Management and Commerce Innovations, 2348-7585, 3.

[5] Ackermann, F. \& Eden, C. (2011). Making strategy: Mapping out strategic success. London, England: Sage.

[6] Adeoye, O. (2013). The impact of business environment on entrepreneurship performance in Nigeria, computing, information systems. Development Informatics \& Allied Research, 4, 4.

[7] Adu, E. A. (2016). The impact of external business environment factors on performance of small \& medium sized enterprises in the pharmaceutical industry in Kumasi metropolis. Unpublished thesis for master of business administration, Kwame Nkrumah University of Science and Technology.

[8] Agranoff, R. (2012). Collaborating to manage. Washington, D.C: Georgetown University Press.

[9] Aldehayyat, J. S. (2011). Organizational characteristics and the practice of strategic planning in Jordanian hotels. International Journal of Hospitality Management, 30(1), 192-199.

[10] Aldehayyat, J. S. \& Al Khattab, A. A. (2013). Strategic planning and organizational effectiveness in Jordanian hotels. International Journal of Business and Management, 8(1), 11-25.

[11] Aldehayyat, J. S. \&Twaissi, N. (2011). Strategic planning and corporate performance relationship in small business firms: evidence from a Middle East country context. International Journal of Business and Management, 6(8). doi:10.5539/ijbm.v6n8p255

[12] Ansoff, H. (2007). Implementing strategic management. Prentice hall, 2nd edition.

[13] Ansoff, I. (1970). Corporate strategy; an analytic approach to business policy for growth and expansion. New York: McGraw-Hill

[14] Arasa, R. \&K'Obonyo (2012). The relationship between strategic planning and firm performance. International Journal of Humanities and Social Science, 2 (22), 71-93.

[15] Arasa, R., \&K’Obonyo, P. (2012). The Relationship between Strategic Planning and Firm Performance. International Journal of Humanities and Social Science, 2(22).

[16] Armstrong, J. S. (1982). The value of formal planning for strategic decisions: review of empirical research. Strategic Management Journal, 3(3), 197-211. Retrieved from http://www3.interscience.wiley.com/cgibin/jhome/2144

[17] Atow-Zahir, A. A. (2012). The relevance of strategic planning on organizational growth in the public sector: Acase study of Ghana Shippers Authority. Unpublished thesis for master of business administration, Kwame Nkrumah University of Science and Technology.

[18] Bahaee, M. S. (1992). Strategy-Comprehensiveness Fit and Performance. Australian Journal of Management, 17(2), 195-215.

[19] Bayode, B. O. \& Adebisi, A.O (2012). Strategic environmental scanning and organization performance in a competitive business environment. Economic Insights - Trends and Challenges, l xiv (1), 24-34. 
[20] Boateng, P. A., Ganu, J. \& Amponsah, E. B. (2015). Strategic planning process formality and institutional performance. European Journal of Business and Management, 7(20), 132-142. http://iiste.org/Journals/ index.php/EJBM/article/view/23839/24410

[21] Bondaruk\&Komarovskiy (2015). Strategic planning for regional development on the basis of the concept of "point of growth. Journal of Public Administration, Finance and Law, 7, 16-21.

[22] Borins, S. (2014). The persistence of innovation in government. Washington, Dc: The Brookings institution.

[23] Bouazza, A.B., Ardjouman, D., Abada, O. (2015). Establishing the factors affecting the growth of small and medium-sized enterprises in Algeria. American International Journal, 4(2).

[24] Boyd, B. K., \&Reuning-Elliott, E. (1998). A Measurement Model of Strategic Planning. Strategic Management Journal, 19(2), 181-192. Retrieved from http://www.jstor.org/stable/3094063

[25] Bracker, J. S., \&Pearson, J. N. (1986). Planning and Financial Performance of Small, Mature Firms. Strategic Management Journal, 7(6), 503-522. http://www.jstor.org/stable/2486136

[26] Bresser, R. K. \& Bishop, R. C. (1983). Dysfunctional Effects of Formal Planning: Two Theoretical Explanations. The Academy of Management Review, 8(4), 588-599. Retrieved from http://www.jstor. org/stable/258260

[27] Bryson, J. M., Ackermann, F. \& Eden, C. (2016). Discovering collaborative advantage: the contributions of goal categories and visual strategy mapping. Public Administration Review, 76(6), 912-925.

[28] Bryson, J.M (2018). Strategic planning for public and nonprofit organizations, 5th edition, Wiley Published.

[29] Burns, T. E. \& Stalker, G. M. (1961). The management of innovation. University of Illinois at UrbanaChampaign's Academy for Entrepreneurial Leadership Historical Research Reference in Entrepreneurship.

[30] Capon, N., Farley, J. U \& Hulbert, J.M (1994). Strategic planning and financial performance: More evidence. Journal of Management Studies. 31:1 (Jan. 1994) 0022-2380.

[31] Chae, M. S.\& Hill, J. S. (1997). High versus low formality marketing planning in global industries: determinants and consequences. Journal of Strategic Marketing, 5(1), 3-22.

[32] Chae, M. S., \& Hill, J. S. (2000). Determinants and benefits of global strategic marketing planning formality. International Marketing Review, 17(6), 538-563.

[33] Debarliev, S. \&Trpkova, M. (2011). Strategic planning practice in transition economies: Empirical evidence from the Macedonian. Business and Economic Horizons, 4(1), 27-39. ISSN: 1804-1205. From www.pieb.cz

[34] Dess, G. G., \& Beard, D. W. (1984). Dimensions of organizational task environments. Administrative Science Quarterly, 52-73.

[35] Duncan, R. B. (1972). Characteristics of organizational environments and perceived environmental uncertainty. Administrative Science Quarterly 17, 313-327.

[36] Dutton, J. E., \&Duncan, R. B. (1987). The Influence of the Strategic Planning Process on Strategic Change. Strategic Management Journal, 8(2), 103-116. Retrieved from http://www.jstor.org/stable/ 2485975

[37] Eisenhardt K. M. (1989). Agency theory: An assessment and review. The Academy of Management Review, 14 (1), 57-74.

[38] Falshaw, J. R., Glaister, K. W.\&Tatoglu, E. (2006). Evidence on formal strategic planning and company performance. Management Decision, 44(1), 9-30. DOI 10.1108/00251740610641436

[39] Ferdinand, J., Graca, M., Antonacopoulou, E., \&Easterby-Smith, M. (2004). Dynamic capability: tracking the development of a concept. In fifth European Conference on Organizational Knowledge, Learning and Capabilities, Innsbruck (Austria). 2-4.

[40] Fredrickson, J. W., \& Mitchell, T. R. (1984). Strategic Decision Processes: Comprehensiveness and Performance in an Industry with an Unstable Environment. The Academy of Management Journal, 27(2), 399-423. http://www.jstor.org/stable/255932

[41] Freeman S. \& Reid I. (2006). Constraints facing small western firms in transitional markets. European Business Review, 18 (3), 187-213.

[42] Glaister, K. E., Dincer, O., Tatoglu, E., Demirbag, M., \& Zaim, S. (2008). A causal analysis of formal strategic planning and firm performance: Evidence from an emerging country. Management Decision, 46(3), 365 - 391. Retrieved from http://dx.doi.org/10.1108/00251740810863843

[43] Grant, R. M. (2003). Strategic Planning in a Turbulent Environment: Evidence from the Oil Majors. Strategic Management Journal, 24(6), 491-517. Retrieved from http://www.jstor.org/stable/20060552

[44] Ida S, Azahari, Munauwar, \&Rushami Z. (2015). Strategic planning and firm performance: a proposed framework. International Academic Research Journal of Business and Technology. 1(2), 201-207.

[45] Johan, H. Thompson, A. A. \& Strickland, A. J. (2010).Crafting and executing strategy: South African Edition.

[46] Johnson, G., Scholes K. \& Whittington R. (2008). Exploring corporate strategy. Eighth edition, Pearson education limited. 
[47] Karim, M. G. (2018). The impact of strategic planning on crisis management styles in the 5-star hotels. Journal of Hotel \& Business Management, 7, 171.

[48] Kinicki, A, \& Williams, B. K. (2011). Management: A Practical Introduction, 5/e.

[49] Kowo, S. A. (2018). Impact of external business environment on organizational performance. International Journal of Advanced Research and Innovative Ideas in Education, 4(3), 2395-4396.

[50] Kreither R. (2006). Management. 2nd edition, USA publishers.

[51] Kukalis, S. (1991). 'Determinants of strategic planning systems in large organizations: A contingency approach', Journal of Management Studies, 28, pp. 143-160.

[52] Lindsay, W. M., \& Rue, L. W. (1980). Impact of the Organization Environment on the Long-Range Planning Process: A Contingency View. The Academy of Management Journal, 23(3), 385-404. Retrieved from http://www.jstor.org/stable/255507

[53] McIlquham-Schmidt, A. (2010). Appraising the empirical evidence of the relationship between strategic planning and corporate performance. School of Business, Aarhus University, Department of Management. Retrieved from www.hha.dk/man/cmsdocs/WP/2010/wp2010_03.pdf

[54] Meier, K. J. \&O'toole, L. J. Jr. (2009). The proverbs of new public management: lessons from an evidence-based research agenda. The American Review of Public Administration, 39(1), 4-22.

[55] Michael A. Germano, Shirley M. \& Stretch-Stephenson(2012). Strategic value planning for libraries. The Bottom Line, 25(2), 71-88.

[56] Miller, C. C., \& Cardinal, L. B. (1994). Strategic Planning and Firm Performance: A Synthesis of More than Two Decades of Research. The Academy of Management Journal, 37(6), 1649-1665. Retrieved from http://www.jstor.org/stable/256804

[57] Miller, D. (1987). Strategy making and structure: analysis and implications for performance. Academy of Management Journal, 30(1), 7-32.

[58] Miller, D. (1987). The structural and environmental correlates of business strategy. Strategic Management Journal, 8(1), 55-76.

[59] Mintzberg, H. (1993). The pitfalls of strategic planning. California Management Review, 36, 32-32.

[60] Mintzberg, H. (1994). The rise and fall of strategic planning, Prentice-Hall, Englewood Cliffs, NJ.

[61] Mohd, W., Idris, S., \& Momani, R. A. (2013). Impact of Environmental Dynamism on Marketing Strategy Comprehensiveness and Organizational Performance. International Journal of Business \& Management, $8(9)$.

[62] Moussetis, R. C. (2014). Ansoff revisited: how Ansoff interfaces with both the planning and learning schools of thought in strategy. Journal of Management History. https://doi.org/10.1108/1751134111 1099556.

[63] Muhammad, W. J. K. (2014). Strategic Planning and Reality of External Environment of Organizations in Contemporary Business Environments. Business Management and Strategy, 5(2), 165-182.

[64] Njoroge J. K., Ongeti W. J., Kinuu D. \&Kasomi, F. M. (2016). Does External Environment Influence Organizational Performance? The Case of Kenyan State Corporations. Management and Organizational Studies, 3(3), 41-51.

[65] Nooraie, M. (2012). Factors Influencing Strategic Decision-Making Processes. International Journal of Academic Research in Business \& Social Sciences, 2(7).

[66] O'Reagan N. \&Ghobadian (2007). Formal strategic planning: annual riddance of wheel of success? Strategic Change. 16:11-22

[67] Odongo, M. S. \& Datche, O. (2015). Effects of strategic planning on organizational growth . International Journal of Scientific And Research Publications, 5(9), 1-15.

[68] Oginni, B. O. \& Adesanya, A. S. (2013). Business environmental factors: implications on the survival and growth of business organisations in the manufacturing sector of Lagos metropolis. Business and Management Research, 2(3), 146-155.

[69] Ontorael, R., Suhadak\&Mawardi, M. (2017). Analysis of the influence of external and internal environmental factors on business performance: A study on micro small and medium enterprises (MSMES) of food and beverage. Russian Journal of Agricultural and Socio-Economic Sciences, 66(6), 47-56

[70] Pearce, J. A. \& Robinson, R. B. (2013). Strategic management: Planning for Domestic \& Global Competition, Thirteenth Edition, McGrawHill Companies, Inc., New York.

[71] Pearce, J. A. \& Robinson, R. B. (2014). Strategic Management 14th Edition. Boston.

[72] Poulis, E., Poulis, K. \& Christodoulou, I. (2013). Developing Dynamic Capabilities to Address 'Mutating' Forces. Track: 'Dynamic Capabilities: Theoretical Approaches and Practical Applications', European Academy of Management (EURAM) 
[73] Prescott, E. C. (1986). Theory ahead of business-cycle measurement. In Carnegie-Rochester Conference Series on Public Policy. 25. 11-44.

[74] Priem, R. L., \& Butler, J. E. (2001). Is the Resource-Based "View" a Useful Perspective for Strategic Management Research? The Academy of Management Review, 26(1), 22-40. Retrieved from http://www.jstor.org/stable/259392

[75] Priem, R. L., Rasheed, A. M., \&Kotulic, A. G. (1995). Rationality in strategic decision processes, environmental dynamism and firm performance. Journal of Management, 21(5), 913-929.

[76] Ridwan \& Ina, P. (2015). Influence business environment on the organization performance. International Journal of Scientific \& Technology Research, 4(04), 283- 293.

[77] Risseeuw, P., \&Masurel, E. (1994). The role of planning in small firms: empirical evidence from a service industry. Small Business Economics, 6(4), 313-322.

[78] Robbins, S. P. and Coulter, M. (2012). Management, 11/e. New York. Prentice Hall.

[79] Saint, W. (2015). Tertiary education and economic growth in Sub-Saharan Africa: The World Bank report.International higher education, 54.

[80] Scharmer, C. O. (2016). Theory U: leading from the future as it emerges (2nd ed.). San Francisco: BerrettKoehler.

[81] Schraeder, M. (2002). A simplified approach to strategic planning: practical considerations and an illustrated example. Business Process Management Journal, 8(1), 8-18.

[82] Schwenk, C. R., \& Shrader, C. B. (1993). Effects of formal strategic planning on financial performance in small firms: A meta-analysis. Entrepreneurship Theory and Practice, 17, 53-53.

[83] Shenhar, A. J. (2001). One size does not fit all projects: exploring classical contingency domains. Management Science, 47(3), 394-414.

[84] Shrader, C. B., Mulford, C. L., \& Blackburn, V. L. (1989). Strategic and operational planning, uncertainty, and performance in small firms. Journal of Small Business Management, 27(4), 45-60.

[85] Shraeder, M. (2002). A simplified approach to strategic planning: Practical considerations and an illustrated example. Business Process Management Journal, 8 (1), 8-18. Retrieved fromhttp://www.emeraldinsight.com/ research registers

[86] Suddaby, R., Bitektine, A. \& Haack, P. (2017). Legitimacy. Academy of Management Annals, 11(1), 451-478.

[87] Suklev, B. \&Debarliev, S. (2012). Strategic planning effectiveness comparative analysis of the macedonian context, economic and business review, 14(1), 63-93.

[88] Teece, D. J., Pisano, G., \&Shuen, A. (1997). Dynamic capabilities and strategic management.

[89] Torok, M. (1997). Strategic planning. Baltimore, MD: Johns Hopkins University Institute for Policy Studies.

[90] Wang, C., Walker, E. A. \& Redmond, J. L. (2007). Explaining the lack of strategic planning in SMES: the importance of owner motivation. International Journal of OrganisationalBehaviour, 12(1), 1-16.

[91] Wiersema, M., \&Bantel, K. (1992). Top management team demography and corporate strategic change. Academy of Management Journal, 35, 91-121

[92] Williams, M. A. (2009). Privacy management, the law and business strategies: A case for privacy driven design. Paper presented at the CSE '09. International Conference on Computational Science and Engineering, 29-31.

\section{AUTHORS' BIOGRAPHY}

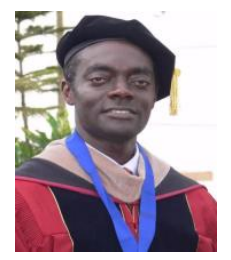

Peter Agyekum Boateng is Senior Lecturer and currently serves as Rector at the Techiman Campus of Valley View University. Areas of research interest include, among others, strategic management, organisational behaviour, managerial leadership and systems thinking.

Citation: Peter Agyekum Boateng. “ Environmental Characteristics: Moderator of Strategic Planning Process Formality and Performance " International Journal of Managerial Studies and Research (IJMSR), vol 7, no. 1, 2019, pp. 22-33. doi: http://dx.doi.org/10.20431/2349-0349.0701004.

Copyright: (C) 2019 Authors. This is an open-access article distributed under the terms of the Creative Commons Attribution License, which permits unrestricted use, distribution, and reproduction in any medium, provided the original author and source are credited. 